\title{
Specifičnost komunikace policistů s osobami pod vlivem omamných a psychotropních látek
}

\section{Specificity of Communication of Policemen with Persons under the Influence of Narcotic and Psychotropic Substances}

Dagmar Kopencová*

Vysoká škola finanční a správní, Praha

\begin{abstract}
Abstrakt
Příspěvek je zaměřen na bezpečnou komunikaci př́slušníků Policie České republiky s osobami pod vlivem omamných a psychotropních látek. Úkolem př́slušníků policie je udržovat veřejný pořádek, prověřovat a vyšetřovat trestnou činnost. Jsou v první linii, řeší krizové situace na veřejnosti a čím dál častěji se musí vypořádat s osobami pod vlivem omamných a psychotropních látek. Při odhalování trestné činnosti získávají informace v podobě výslechů od podežrelých osob, obviněných, svědků a poškozených, kteří zneužívají návykové látky. Taktika komunikace a výslechu těchto osob je pro policisty velmi důležitá součást jejich pracovní činnosti.
\end{abstract}

Klíčová slova: nebezpečí, komunikace, omamné a psychotropní látky, pachatel, policie.

\section{1. ÚVOD}

Policie České republiky je jednotný ozbrojený bezpečnostní sbor zřízený zákonem České národní rady ze dne 21. června 1991 - slouží veřejnosti. Jejím úkolem je chránit bezpečnost osob a majetku, chránit veřejný pořádek a předcházet trestné činnosti [11].

Úkolem policie je tedy chránit pořádek a vnitřní bezpečnost ve státě. Př́i vykonávání své práce mohou nastat krizové situace, které ohrožují nejen je samotné, ale i civilní osoby, které se nacházejí v nejbližším okolí či jsou př́ímo účastníky nebezpečné události. Stejně tak se ocitá v nebezpečí obecný nebo soukromý majetek nebo obecný zájem státu.

Jedním bezprostředním nebezpečím jsou bezesporu omamné a psychotropní látky (OPL). Omamné a psychotropní látky

\begin{abstract}
The paper focuses on the safe communication of members of the Police of the Czech Republic with persons under the influence of narcotic and psychotropic substances. The task of the police is to maintain public order, to investigate and investigate crime. They are in the front line, dealing with public crisis situations and increasingly have to deal with people under the influence of narcotic and psychotropic substances. In detecting crime, they receive information in the form of interrogations from suspects, accused persons, witnesses and victims who abuse substance abuse. The tactics of communication and interrogation of these persons is a very important part of their work.
\end{abstract}

Keywords: danger, communication, narcotic and psychotropic substances, perpetrator, police.

neboli drogy upravuje zákon č. 168/1997 Sb., o návykových látkách v platném znění, nařízení vlády č. 463/2013 o seznamech návykových látek v platném znění a vyhláška č. 72/2014 Sb., o evidenci a dokumentaci návykových látek a př́pravků a prekurzory zákon č. 272/2013 Sb., o prekurzorech drog v novelizované podobě.

Pod pojem droga tedy lze obecně zařadit jed, léčivo nebo narkotikum. Drogou je jakákoliv látka, která způsobuje závislost u člověka, látka určená na diagnózu, léčení, prevenci nebo zmírnění onemocnění a také psychoaktivní látka, která mění myšlení, pamět', vnímání a náladu. Psychoaktivní látka po vstupu do organismu mění jednu nebo více jeho funkcí. V souvislosti s opakovanou aplikací psychoaktivních látek dochází ke stavu závislosti. Tělesná závislost vyplývá z chronického, opakovaného uživání drog a je charakterizována tolerancí a existencí abstinenčních příznaků pro 
konkrétní drogu. Vývoj tolerance není však u každého člověka stejný, a proto ho ani nelze předem předpovědět. Př́ičina toxického efektu drogy může být doprovázena také zvýšenou tolerancí organismu na danou drogu. Abstinenční př́znaky vznikají tehdy, když dojde k náhlému přerušení dodávání drogy do organismu, resp. k výraznému snížení dávky dané drogy v organismu, který je již na danou látku zvyklý.

Každá skupina drog (psychoaktivních látek) vykazuje různou míru psychické závislosti chápané jako potřeba dané drogy. Jedinec s psychickou závislostí často věří, že bez konkrétní drogy a její neustálého užívání, nemůže dál normálně fungovat. Projevuje se u něj neodolatelné nutkání užít drogu a drogu získávat jakýmkoli prostředkem. Navzdory některým konstantním a specifickým příznakům ovlivnění drogou, existuje značná variabilita v účincích dokonce i u konkrétního jedince. Významnou roli může v konkrétních sledovaných účincích sehrát i pohlaví uživatele. Jedním z ovlivňujících faktorů možné závislosti na droze jsou tzv. peristatické faktory, tj. faktory vlivu skupiny, okolí, kulturních stylů a jiných sociologických aspektů a souvislostí.

Př́́slušníci policie ČR se stále častěji setkávají s osobami ovlivněnými drogami různého druhu a jsou nuceni řešit problémové situace na ulici i na služebně. Jedná se zejména o uniformované př́slušníky policie a poté o kriminalisty a vyšetřovatele. Zejména uniformovaní policisté jsou mladí a ve službě krátkou dobu.

Z důvodů politických a ekonomických tlaků dochází v určitých periodách ke snižování stavu policejního sboru, odchodu starších zkušených policistů znalých drogové problematiky z praxe, a poté k nabírání nových mladých policistů, kteří ovšem nemají potřebné znalosti a zkušenosti policejní práce a chybí jim možnost převzít praktické dovednosti a zkušenosti od policistů déle sloužících.

Jedním z problémů policejní práce je jednání s osobami pod vlivem drog, rozpoznání těchto osob a taktéž možnosti získání informací k různým událostem a okolnostem, které jsou důležité k objasnění proběhlé události. Na jejich základě může dojít k ochraně života nebo majetku jiné osoby.

\section{VLIV OMAMNÝCH A PSYCHOTROPNÍCH LÁTEK A LÉČIV NA VNÍMÁNÍ, ZAPAMATOVÁNÍ A OSOBNOST ČLOVĚKA PODLE POLICEJNÍ PRAXE}

Každá látka v těle má určitý specifický vliv na člověka, at' již pozitivní nebo negativní. Omamné a psychotropní látky působí na funkci mozku a způsobují možné změny v chování, jednání jedince či vnímání prožívaných událostí. Toto působení drogy může být dočasné nebo trvalé $\mathrm{v}$ závislosti na délce použivání těchto látek. Pro policistu, zejména vyšetřovatele je důležité znát, jak různé druhy drog dokážou ovlivnit chování člověka při kontaktu s policií, a zejména jak se osoba pod vlivem drogy bude chovat při výslechu. Tento př́íspěvek popisuje postřehy policistů, kteří přicházejí s těmito osobami denně do styku a musí se s nimi podle zákona vypořádat.

Jednání s osobou pod vlivem drog je pro policisty velmi problematická záležitost. Policista musí brát v úvahu, že každá osoba je individuální a i droga na každou osobu bude působit jinak, individuálně, tak např. opiáty navozují př́ijemné stavy, hašiš přidává smyslovým dojmům silný emocionální nádech, kokain př́iemně vzrušuje. Policista musí také rozlišovat, z jakého důvodu od osoby získává informace, zda půjde o základní informace ke zjištění totožnosti, $\mathrm{k}$ jejímu stavu nebo informace důležité pro přestupkové či trestní řízení. Poté je důležité, zda policista tuto osobu vyslechne na ulici, popř. na policejním oddělení. A nakonec v jakém procesním postavení (osoba podezřelá, obviněná, v roli svědka, poškozeného) se osoba pod vlivem drog nachází. Dále je třeba, aby poznal, zda je vyslýchaná osoba utlumená, dezorientovaná, vybuzená či agresivní. Zná-li policista, pod vlivem jaké psychotropní látky se uživatel nachází a zda je občasný či stálý uživatel OPL, potom může upravit chování a otázky tak, aby se sám nedostal do nebezpečné situace a ještě získal od uživatele drog výpověd'.

Vlastní komunikace s osobou pod vlivem návykové látky musí být velmi obezřetná a cílevědomá. Obecně lze doporučit, aby komunikace s takovou osobou byla co nejvýstižnější a co nejkratší. Přri kontaktu by se měl policista snažit, aby nedocházelo ke zbytečným slovním výměnám, a tak předejít možným projevům agrese osob uživajících OPL. Při rozhovoru nebo pouhém setkání s toxikomanem, který porušil zákon, vždy jednat z pozice autority. Při komunikaci není vhodné být submisivní (nepodřizovat se, nepřijímat způsob jednání osoby), na druhé straně je krajně nevhodné, aby se policista choval agresivně a arogantně. V rozhovoru musí být rázný, autoritativní a jednoznačný. Intonace hlasu by měla být bez citového zabarvení. Mimoverbální projevy (mimika, gestikulace) by se měly používat pokud možno v co nejmenší míře, protože tyto mohou být toxikomanem pochopeny jako projev agresivity proti jeho osobě. Policista by měl s touto osobou neustále udržovat oční kontakt, což osobu řadí do role „toho nižšího“ a znesnadňuje mu pocit lhaní. Pokud dojde k tomu, že dojde k slovní rozepři, i přesto, že se tomu bude snažit policista vyhnout, je dobré v takové situaci neříkat kategorické „ne“. Je dobré použít např. obrat typu: „Myslím si, že by bylo lepší, ale na druhé straně.“, a obratnou argumentací přimět toxikomana, aby postupně vyslovoval souhlas s výroky policisty. Také je nutno mít pro policistu $\mathrm{v}$ patrnosti to, aby při slovním výpadu ze strany toxikomana nereagoval podrážděně, ale musí tento atak odrazit klidem, ignorovat a tím toxikomana donutit opět k tomu, aby musel argumentovat, nebo ztratí svou výhodnou pozici ve vzájemné komunikaci. Např. řekne-li toxikoman „vy pořád otravujete lidi...", měl by policista odpovědět s ledovým klidem: „můžete mít pravdu, ale jak jinak byste to řešil vy..." Pokud osoba pod vlivem drog mluví pomalu, měl by policista mluvit rovněž pomalu. Jednání policisty musí být vcelku klidné, bez emocí, bez nervozity a to by mělo být patrné i ze způsobu komunikace a z verbálního projevu.

Zde jsem shromáždila od policistů jejich postřehy a znalosti, jak se osoba pod vlivem jednotlivých drog může chovat a jak je schopna vypovídat.

\subsection{Drogy kanabisového typu \\ Nejběžněji dostupnou drogou je:}

- Marihuana - U osob, které užijí marihuanu, dojde ke změně vnímání času, čas se podle nich prodlužuje, tedy zpomaluje, nejsou schopny se tedy v čase orientovat. Stejně tak mají problém se orientovat $\mathrm{v}$ prostoru.

Dochází k zostření smyslů. Pokud jde o náladu takové osoby, může dojít ke skleslosti nebo naopak je osoba bezdůvodně nápadně veselá až rozjařilá, směje se bez důvodu prakticky všemu a její 
smích není k utišení. V takové chvíli je zbytečné ji pokládat jakoukoliv otázku. Je mnohem lepší jí dotazy psát, nebot' si položenou otázku vůbec nemusí zapamatovat, popř́padě je schopna zapomenout i to, o čem před chvíli mluvila.

Při akutní intoxikaci (při vyšších dávkách) se muže vyskytnout zmatenost, ztráta pozornosti, pocity pronásledování, halucinace, zvukové a optické dotykové iluze. Dochází i k poruchám krátkodobé paměti. Ztrácí se motivace k jakékoliv činnosti.

Po odeznění účinku se dostaví únava, zmatenost a otupělost.

- Hašiš - Nízké dávky z počátku mohou způsobit neklid, úzkost, později navozují zasnění, klidnou pohodu s chutí na sladké pochutiny. Osoba se chová obdobně jako uživatel marihuany, prožitky jsou však intenzivnější. $\mathrm{V}$ dané chvíli se může chovat pošetile, rozpustile jako malé dítě. Může začít zpívat, smát se, běhat po místnosti.

Dochází ke změnám ve smyslovém vnímání, je zvýšena její citlivost, zejména u zrakových a sluchových vjemů, zvuky a barvy jsou jasnější. Taktéž intenzita čichových, hmatových a chut'ových vjemů je vyšší, a to ovlivňuje schopnost reálného myšlení a uvažování, například při kapajícím kohoutku může slyšet vodopád.

Krátkodobá pamět’ je poškozena, dochází k zapomínání začátku věty ještě před jejím dokončením a subjekt velmi často ztrácí pozornost. Dochází k časovým rozporům, prostor se jim mění před očima. Poruchy paměti mohou přetrvávat týdny po vysazení drogy.

U vyšších dávek se mohou dostavit zrakové nebo sluchové halucinace s případnými poruchami paměti, dochází $\mathrm{k}$ jejímu zhoršování a $\mathrm{k}$ jejím výpadkům.

\subsection{Drogy halucinogenního typu}

Rozdělujeme je nejčastěji na:

- Lysohlávky (Psilocybe) - Po požití je osoba neklidná, mírně ospalá a může velmi často zívat. Chová se obdobně jako po požití alkoholu, má poruchy koordinace.

Dochází u ní ke změně vnímání reality, která se projevuje tak, že se ztrácí v časoprostoru, není tedy schopna určit čas a prostorové souvislosti. V intoxikaci vnímá ostatní lidi s deformovanými tvářemi a údy, vlastní tělo vnímá jinak, dochází k depersonalizaci a k pseudohalucinacím. Zesiluje se vnímání barev a zvuků, které mohou vést až $\mathrm{k}$ zrakovým halucinacím. Intoxikovaný se může neuváženě a ukvapeně rozhodovat (skočit z nějaké výšky) Dotazy policistů vnímá nelibě jako vyrušování, žijí ve svém imaginárním světě, není možné s nimi komunikovat.

- Kaktus Lofofora Wiliamsova (Lophophora Williamsii) (nebo také lidově San Pedro kaktus). Po požití mezkalinu mohou příznaky zrakových iluzí trvat až 10 hodin. Na začátku je osoba euforická, bezdůvodně se směje a vtipkuje, má pocit, že nemůže ovládat své tělo, její končetiny mění proporce a velikost. Vidí barvy, které ve skutečnosti v daném prostoru nejsou, má také čichové halucinace. Předměty mohou měnit velikost, je schopna vidět bájná zvířata. Barevně může vnímat i hudbu nebo různé zvuky. Otázky na prostor a čas budou nevěrohodné, protože její orientace je zhoršená. Taktéž určení místa, odkud slyšela nějaký zvuk, bude zhoršené.

Při předávkování může docházet k psychózám.

- Rostliny čeledi lilkovitých, například durman (Datura sp.) neboli panenská okurka, rulík zlomocný (Atropa bella-donna) a blín černý (Hyoscyamus niger).
Uživatelé těchto drog nejsou př́liš početní, protože u těchto drog se těžko odhaduje, kolik si této látky vzít. Pokud se policista setká $\mathrm{s}$ takto ovlivněnou osobou, nebude s ní možná žádná komunikace. Osoba bude nestabilní, bude trpět závratěmi, je dezorientována, a bude mít halucinace všeho druhu včetně tělových (snaží se z těla vytáhnout imaginární předměty, smést ze sebe brouky či mravence). Mohou se všemu smát, stejně tak mohou být agresivní vůči sobě.

Nejsou schopni rozlišit realitu od jejich vidění. Může se snadno zranit a to i smrtelně, nebot' se jí často zdá, že může létat. Stav trvá až 24 hodin, kdy dochází k celkovému útlumu až naprostému vyčerpání. Je zde možná i kombinace semen durmanu a marihuany, stav často vyžaduje lékařské ošetření.

- LSD (Lysergic acid diethylamide) - nízká dávka vyvolává většinou euforii. Osoba, která požila LSD si vše v okolí uvědomuje a dokáže se kontrolovat. Dokáže se i orientovat v prostoru i času. Je tedy možné s ní komunikovat a získat věrohodné informace. Její vědomí je nezměněno a zachováno. Osoba je sdílná a upovídaná.

Ovšem při vyšší dávce již neovládá svoji vưli a dochází k poruchám vědomí. Obecně lze říci, že LSD účinkuje na každého trošku jinak, účinky jsou tedy nepředvídatelné. Může docházet k iluzím, může vnímat a rozlišit realitu a chybné vjemy, ale pod vlivem př́ijemné vidiny (např́íklad slyší zvuky a cítí doteky, které se zdají velmi reálné, ale ve skutečnosti neexistují) se nechává unášet ve světě fantazie, tudíž sdělí naprosto nepravdivé údaje.

Vysoké dávky způsobují halucinace, dochází k poruchám vnímání, ke ztrátě kontaktu s realitou, ke ztrátě volní kontroly, myšlení, prožívání a jednání. Nemá odhad časový a prostorový, dochází ke změnám barev. Jedinec má velmi často pocit, že tento stav nelze změnit, je trvalý, bezčasový, tudíž se u něho projevuje strach, úzkost a panická hrůza. Velmi často vidí kolem sebe $\mathrm{v}$ prostoru samé oči, točící se barevné terče, orientální vzory a točící se či vlnící barevné plochy. S takovým intoxikovaným se nedá rozumně domluvit, jeho odpovědi vzhledem ke ztrátě soustředěnosti jsou těžkopádné, není schopen dokončit myšlenku. V takovém stavu může dojít k pokusu o sebevraždu.

Delší doba zneužívání LSD může způsobit i psychické poruchy ve smyslu schizoidní poruchy osobnosti, to záleží na genetice osoby, které vedou ke změnám chování. Policista ji rozpozná tak, že osoba není schopná racionálního myšlení, dochází k rychlým střídáním nálad, změnám chování, $\mathrm{k}$ halucinacím a bludům.

\subsection{Drogy opiátového typu}

Nejméně užívaná droga tohoto typu je u nás opium.

- Opium - Po požití opia se osoba dostane do stavu euforie a ztrácí pocit tělesné a duševní bolesti. Osoba se cítí klidně, opojně bez halucinogenních vizí. Po určité době bude osoba ospalá a nakonec usne. Policista musí zjistit, kdy si narkoman vzal svoji poslední dávku. Po probuzení bude mít totiž abstinenční příznaky a to jak fyzické, tak psychické a v tomto stavu již nebude schopen žádné komunikace. Tyto osoby zneužívající opium jsou většinou osoby arogantní, egoistické, nesnášenlivé a lhoucí.

- Morfin - U morfinu bude euforie výraznější. Opojený je klidný, št’astný a vyrovnaný. Nemá žádné starosti. Policista uvidí před sebou velmi sebevědomou osobu, která je schopna normální aktivní komunikace. Ovšem po odeznění drogy nastoupí abstinenční příznaky, které tuto osobu vyřadí z běžného života i z možnosti provádění jakýchkoliv procesních úkonů. Dochází například k depresím, průjmu zvracení, poruchám krevního oběhu. 
Při vysokých dávkách působí morfin hypnoticky a narkoman bude mít dýchací problémy.

- Heroin - působí obdobně jako jiné opiáty, pouze jeho nástup je rychlejší, zejména injekčním podáním. Protože proniká téměř okamžitě do mozku, způsobí na několik hodin (1-7 hodin) oblouznění. To znamená, že v tuto dobu policista s tímto narkomanem nic nezvládne učinit. Narkoman je uvolněný i svalově, je naprosto pasivní, klidný, s blaženým výrazem a je mimo realitu, protože se mu zamlžily všechny smysly. Po určitém časovém úseku je však schopen komunikovat bez zábran. Policista by měl být obezřetný, protože narkoman je schopen jakéhokoliv fyzické aktivity. Pokud je uživatel akutně intoxikován, je utlumený, většinou nedokončuje věty, jeho pozornost je jen občasná, je schopen být apatický, usínat. Policista musí mluvit v krátkých větách, klást jednoduché dotazy, které často opakuje, mluvit nahlas a srozumitelně artikulovat. Pokud drogu zneužívá dlouhou dobu, je nebezpečný, jeho povaha se mění k horšímu, vzniká rozklad osobnosti. U výslechu je třeba počítat s těžkými poruchami paměti, egocentrismem a záchvaty úzkosti vedoucími až k paranoidním stavům, kdy může být velmi nebezpečný.

\subsection{Drogy kokainového typu}

\section{Jde o jedny z nejnebezpečnějších drog.}

- Kokain - Pokud kokain užije osoba, která ho nezneužívá a nezná, většinou jí spíše bude špatně. Bude trpět úzkostí, závratí a po fyzické stránce se bude cítit nepř́ijemně. Později po požití, většinou šňupáním, se osoba cítí bděle, bez únavy, plná energie, je veselá, družná, nemá hlad ani žízeň. Touží po pohybu a výkonu. Kokain se totiž dostává prrímo do mozku. To trvá cca 20 minut po aplikaci. Po opadnutí tohoto účinku bude osoba neklidná, přecitlivělá na jakékoliv hlasité zvukové podněty a bude trpět fyzickými potížemi.

Nehrozí produktivní poruchy vnímání (halucinace, iluze) či myšlení (bludy).

Velké dávky vyvolávají vyčerpanost, osoba začne být úzkostná až depresivní. Někdy může být i agresivní. Pokud jde o opakované uživání, narkoman může trpět poruchami vědomí, stihomamem. Kokainisté při chronické otravě vidí velmi malá zvířata a hmyz, dokonce i lidé mohou dosahovat velikosti kolem $10 \mathrm{~cm}$. Velmi často si ubližují, škrábou se do krve na celém těle, chtějí hmyz ze zase setrást. Je-li kokainistů více, mohou se navzájem podporovat takovou měrou, že mají společné vidiny, halucinace, a to i sexuální. Po určité době dochází i těžkým psychickým změnám, například k paranoidní psychóze, které mohou vést až k sebevražedným nebo násilným náladám.

- Crack - Kouření kokainového cracku vyvolává kratší, ale intenzivnější omámení. Policisté uvádějí, že účinek cracku dosahuje vrcholu během prvních 30-60 minut po požití a stejně tak rychle mizí. Intenzivní euforie trvá 5-10 minut.

Uživatelé cracku po určité době závislosti trpí přeludy a halucinacemi a vážně se zhoršuje jejich fyzický stav. Je zde vysoké nebezpečí předávkování.

\subsection{Drogy amfetaminového typu}

Rozlišujeme zejména amfetaminy a metamfetaminy.

- Amfetaminy - po požití osoba je naladěna k velkým psychickým i fyzickým výkonům. Je v té chvíli aktivní, což vede k neustálé potřebě něco dělat. Při výslechu bude neklidná, velmi energická a bdělá.

Při vyšších dávkách se osoby stávají hovorné a velmi hyperaktivní. Dlouhodobé aplikace vedou k stavům úplné vyprahlosti, nedostatky vlastního samostatného uvažování a řízení, nesoustředěnosti, neadekvátního chování. Může docházet ke stavům již viděného a zažitého, přestože nic takového neproběhlo a nic takového nezažil. Je třeba s takovou možností u dlouhodobého narkomana počítat. Takové stavy mohou vést k paranoie a k násilí, pokud začne narkoman věřit, že je ohrožen.

- Metamfetamin (pervitin) - osoba po požití se cítí povzbuzeně, cítí se št’astně. Je nabuzená, necítí bolest. Má velké množství energie. V této době je možné s ní komunikovat. Ovšem je nutno si dávat pozor na to, co osoba vypovídá, nebot' ona si myslí, že všemu rozumí, všechno zná, je výřečná, sebevědomá. U narkomana je nutno počítat i např́klad s nepozorností, je schopen např́klad koukat dlouhou dobu z okna nebo na jiný, pro něj zajímavější podnět, než je policista. Ten musí být trpělivý a otázku opakovat tak dlouho, až ji narkoman pochopí a odpoví. Po určité době, 6-8 hodinách dochází $\mathrm{k}$ hádavosti, skáče všem do mluvy, a poté i k možnému agresivnímu chování. Také je schopen se z ničeho nic dát na nesmyslný útěk, i když utéci není kam. Potřebuje novou dávku. Je zmatený, podrážděný, panický a psychicky dezorientovaný. Nakonec apatický a vyčerpaný. Nastupují pocity úzkosti, depresí, paranoi, halucinace. Může docházet k sebevražedným tendencím.

- Extáze - může způsobit u uživatele dva stavy podle toho, v jaké náladě se nacházel před požitím drogy. Uživatel se tudíž může cítit euforicky, uvolněně, je přátelský, nebo je podrážděný, po fyzické stránce se necítí dobře, je nekomunikativní. Pokud je na diskotéce či jiné taneční party, je schopen po dlouhé hodiny tančit, což velmi často vede k naprostému vyčerpání a kolapsu organizmu. Při výslechu se dobře orientuje, je schopen pravdivě vypovídat, po odeznění účinku extáze se však dostavuje nevolnost, vysoká teplota, zhoršení vidění nebo špatná koordinovanost pohybu. V tomto stavu již není schopen vypovídat.

\subsection{Drogy typu organických rozpouštědel (inhalanty) Nejčastěji uživatelé zneužívají:}

- Toluen, benzín, chloroform, různé čisticí prostředky, rozpouštědla a lepidla. Čicháním těchto látek se dostavují velmi rychle stavy podobné opilosti. Pokud není osoba stálým uživatelem a nepřežene to s dobou čichání, je v určitém stavu libosti, uvolnění, veselé nálady. Policista u takové osoby musí počítat po určité době s nástupem nevolnosti, ztráty koordinace a poruchou řeči. Tzv. dlouhodobí čichači však mohou být velmi nebezpeční. Nelze je vyslýchat, nebot' mají velmi často halucinace a stávají se agresivními. Také mají poškozenou pamět', trpí poruchami a výpadky pamětí.

\subsection{Léčiva}

Mezi léčiva zařazujeme:

- Tlumivé léky: sedativa (zklidňují) a trankvilizéry (zmírňují napětí a úzkost)

Uživatel je zneužívá pro jejich uklidňující schopnost, pro zamezení úzkosti a duševního napětí. Nutno počítat s tím, že tyto léky zpomalují činnost mozku, utlumují centrální nervový systém (mozek a míchu). Narkoman je v myšlení velmi pomalý, má 
poruchy koncentrace. Na otázky může odpovídat zmateně, často mu není rozumět. Je na něm znát velká únava, a to tělesná i duševní. Nakonec je netečný, usíná. Při vyšších dávkách narkoman ztrácí koordinaci, má výpadky paměti, je podrážděný a nedokáže mít správný úsudek. Může být nebezpečný okolí i sám sobě. Pokud uživá léky dlouhodobě, postačují 2-3 měsíce nepřetržitého užívání, a nedostane včas svou obvyklou dávku léčiva, je podrážděný, depresivní, chronicky unavený, úzkostný až panický. Může mít halucinace a v té chvíli je agresivní, protože nedokáže rozeznat realitu od jeho paranoidních vjemů.

- Opioidy: léky proti bolesti, které obsahují př́rodní opiové alkaloidy nebo jsou synteticky vyráběné.

U narkomana, který zneužívá dlouhodobě léky - opioidy, je třeba počítat s tím, že bude ospalý, bez koncentrace, naprosto nesoustředěný, tudíž nebude schopen reagovat na dotazy. Může být verbálně agresivní.

- Stimulanty: na zvýšení pozornosti a energie.

Policista začínajícího uživatele může vyslechnout, protože ten překypuje energií, jeho reakce je rychlá, je velmi pozorný, bdělý. Je schopen vnímat dotazy a promptně na ně odpovídat. Při delším uživání bude narkoman naopak mít sníženou schopnost pozornosti, bude se cítit neustále unaven, vyčerpán. Může mít i násilné chování, nebot' je stále popudlivý a podrážděný. Při dlouhodobém zneuživání má halucinace, je dezorientován a jeho psychotické chování je velmi nebezpečné.

- Antidepresiva: účel je potlačovat deprese.

Tento uživatel bude apatický, malátný. Policista ho nedokáže ničím motivovat. Největším problémem antidepresiv je, že uživatel má velmi často sebevražedné tendence a závratě.

\section{ZVLÁŠTNOSTI TAKTIKY VÝSLECHU U OSOB POD VLIVEM OMAMNÝCH A PSYCHOTROPNÍCH LÁTEK}

Policista je zpravidla první, kdo se dostane do kontaktu $\mathrm{s}$ toxikomanem a stává se vyslýchající osobou, která má zjistit první informace o spáchaném trestném činu. Většinou jde o uniformovaného policistu, zpravidla z pořádkové nebo dopravní policie. Na místo trestného činu se posléze dostaví některý policista $\mathrm{z} \mathrm{SKPV}^{1)}$, kriminalista - operativec nebo vyšetřovatel a ti si většinou tuto osobu přebírají. Jednání s osobou pod vlivem návykových látek klade vysoké nároky na jejich jednání, protože pokud by se policista choval nevhodně, mohlo by to lehce vyprovokovat konfliktní situaci, která může u osoby pod vlivem návykové látky přerůst k agresi. Určit osobu pod vlivem OPL není jednoduché a jde vždy pouze o odhad, jehož míra pravděpodobnosti závisí na osobních zkušenostech policisty, na úrovni jeho znalostí. Lze odhadnout, ve kterých místech a ve kterém čase je pravděpodobnost komunikace s osobami pod vlivem návykové látky nejpravděpodobnější. Při typování osoby pod vlivem návykové látky nebo prímo toxikomana je policista $\mathrm{v}$ nevýhodě, nebot' zpravidla nemůže vycházet z obecných znaků, jako je např. oděv. Při typování takových osob musí vycházet zejména z fyziognomických znaků, z reakcí, verbálního a nonverbálního chování osob. Jestliže je tato osoba dostatečně schopna vnímat

SKPV - Služba kriminální policie a vyšetřování policistu a ihned ho nenapadne, dojde ke vzájemné komunikaci mezi ním a policistou. Jde o složitý proces, nebot' policista musí vyhodnocovat velmi bedlivě hlasový a jazykový projev, zda obsah odpovědí dávají smysl a zároveň sledovat pohyby a jednání této osoby (např. zda jde o přátelský, lhostejný nebo útočný, agresivní projev). Musí také odhadnout, zda osoba nepotřebuje okamžité lékařské ošetření.

Navázání kontaktu s osobou užívající OPL a získávání pravdivých skutečností je mnohdy značně obtížné a je zde nutné mít navíc hlubší znalosti z oblasti psychologie a psychiatrie, a také jisté znalosti o dané problematice.

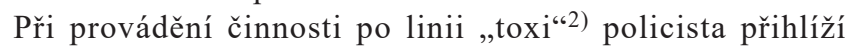
ke zvláštnostem $\mathrm{v}$ reakcích a jednáních osob podezřelých z těchto protiprávních jednání (sklony k agresivitě, útěku, sebepoškozování apod.). Při kontaktu s těmito osobami dbá zvýšené ostražitosti, postupuje uvážlivě a $\mathrm{k}$ jejich střežení přibírá potřebný počet sil a prostředků [12]. U omezení osobní svobody více osob je nezbytné zabránit jejich vzájemnému kontaktu a komunikaci.

Vyslýchající musí s vyslýchanou osobou navázat kontakt. Navázání kontaktu je věcí vyslýchajícího. Prvním hlediskem pro navázání kontaktu je orientační odhad osobnosti vyslýchaného. Vyslýchající při něm zjišt'uje, zda je osoba pod vlivem drog vůbec schopna výslechu. Výslech je náročnou záležitostí, která zcela pohlcuje psychickou kapacitu vyslýchajícího. Ten se totiž musí soustředit na promýšlení a kladení otázek, pozorovat a registrovat verbální i nonverbální projevy vyslýchané osoby, zvažovat při tom věrohodnost výpovědi atd. Stejně tak je důležité sledovat vlastní projevy a pocity v průběhu výslechu. Problémem může být to, pokud si vyslýchající uvědomí, že vyslýchaná osoba je mu silně nesympatická, vzbuzuje v něm negativní pocity apod. V takovém případě nastupuje nutnost zvýšeného sebeovládání, jehož cílem je subjektivní jistota o tom, že pocity antipatie vůči vyslýchanému se nikterak neprojeví v celkové atmosféře výslechu.

Jakým způsobem výslech proběhne, jaká bude jeho kvalita, podstatně ovlivňuje osobnost vyslýchané osoby. Vyslýchané osoby můžou mít různé osobnostní vlastnosti, schopnosti, způsob, jakým se prezentují, různou inteligenci, můžou být sebevědomé nebo naopak plaché, jisté nebo i nejisté. Inteligentní osoby snadno komunikují a rozumí otázkám. Ty, které jsou méně inteligentní nebo mají psychické problémy, se zpravidla hưře vyjadřují, mají malou slovní zásobu, nerozumí otázkám. U osob, které odpovídají sebejistě, není dáno, že odpovídají pravdivě, je zde i možnost, že na sebe chtějí jenom upozornit. Osobám, které jsou nejisté, by se měl nechat určitý prostor a nemělo by se na ně naléhat.

Nevinní lidé zpravidla k věci vypovídají, pokud se nejedná o osoby blízké, a k věci řeknou vše, co si pamatují. U toxikomanů je tomu však trochu jinak, protože ti jsou do věci osobně zainteresovaní (závislí odběratelé) a je pro vyslýchajícího obtížnější takovou osobu přesvědčit, aby vypovídala pravdu. Pro každého, kdo nemluví pravdu, je těžké si vlastní lež zapamatovat, což může být pozitivní pro vyslýchajícího.

U osob užívajících OPL nebo u osob pod jejich bezprostředním vlivem je třeba při výslechu uplatnit zvláštní postupy [4], [13]. Před výslechem by se měl policista co možná nejdokonaleji seznámit s vyslýchanou osobou. Velmi často se jedná o osoby komplikované a rozporuplné, osoby, které jsou psychicky narušené, se kterými je

2) Tzv. policejní toxi tým, zabývající se drogovou trestnou činností 
komunikace velmi obtížná. Tyto osoby jednají mnohdy neadekvátně dané situaci, jsou agresivní, nebo naopak netečné bez jakéhokoliv zájmu o navázání kontaktu. $\mathrm{V}$ př́ípadech, kdy je vyslýchaná osoba bezprostředně pod vlivem drogy, mnohdy nelze výslech provést vůbec, jelikož osoba není výslechu schopna. Výslechem osob závislých na konzumu drog je třeba zjistit zejména, jaké drogy užívá, jak často je užívá, v jakém množství a další otázky [3].

Problémem při výslechu toxikomana je změna schopnosti vnímat jevy kolem sebe po aplikaci drogy. Může dojít k ovlivnění některých smyslových orgánů. Změnou psychických vlastností může být narušena nejen schopnost vnímání, ale i schopnost zapamatování. Je tedy třeba přistupovat $\mathrm{k}$ vyslýchanému s větší trpělivostí a použít všechny dostupné a povolené prostředky, které slouží k vyvolání asociací a mohou pomoci lépe si vybavit pamět'ovou stopu. Nelze vyloučit i to, že osoba, která byla pod vlivem drog svědkem něčeho, si toto skutečně nepamatuje [9].

Ovlivnění výslechu požitím léčiv či drog nemusí být úmyslné. Proto je mnohem nebezpečněš̌i ,ppřevzít“" výpověd' procesní strany bez toho, abychom vůbec věděli, že vyslýchaná osoba byla pod vlivem medikamentů [7]. Prakticky se to velmi lehce může přihodit, nebot' vyslýchaná osoba nemusí jevit žádné známky požití těchto látek a vyslýchající tuto skutečnost při výslechu nezjistí. Mưže to být způsobeno i tím, že vyslýchající se předtím nikdy s vyslýchanou osobou nesetkal a tudíž nezná její běžné chování. Ovlivněná osoba se nemusí chovat nápadně, aby vyslýchající toto ovlivnění zjistil. Následkem toho dochází k tomu, že tato osoba se před soudem obhajuje sdělením, že její výpověd’ musí být brána jako neplatná, nebot' nevěděla, co vypovídá pod vlivem aplikované látky.

Výslech osoby, která je pod vlivem drog, je svým způsobem zvláštní způsob komunikace mezi policistou a vyslýchaným [1]. $\mathrm{Na}$ počátku výslechu je velmi důležité zjistit to, zda je osoba vůbec schopna se časově a situačně orientovat. Mnozí narkomané si totiž po dvou až třech dnech nejsou schopni uvědomit, že byli ve styku s policií. Pokud je taková osoba v postavení svědka, je důležité její důsledné poučení. Výslechy těchto osob se vedou podle obecných taktických postupů vedení výslechu. Pokud musíme zasáhnout do monologu osoby pod vlivem OPL, musíme takto učinit obezřetně. Je zapotřebí si uvědomit jednu skutečnost, že osoby pod vlivem OPL jsou mnohem více náchylné k sugestivním a kapciózním otázkám, jejichž důsledkem může být potom neobjektivnost důkazu. Rozpory ve výslechu je vhodné odstraňovat hned po jejich zjištění.

Chmelík ve své knize uvádí, že doporučuje osoby vyslechnout opakovaně z toho důvodu, kdyby policista např. špatně odhadnul, jak moc byla vyslýchaná osoba drogou ovlivněna a že by to mělo vliv na procesní hodnotu výpovědi. Také dále doporučuje psychiatrické vyšetření takové osoby, což může být důležité $\mathrm{k}$ vyloučení lživé výpovědi, která je u osob užívajících OPL typická [2].

V praxi nedochází k tomu, že by bylo každé osobě, která užívá OPL a je vyslýchána, prováděno psychiatrické vyšetření, jelikož je velmi časově, personálně a finančně náročné. Toto se děje pouze ve výjimečných př́ipadech. U výslechů nastává problém u notorických uživatelů, kteří jsou pod vlivem drogy neustále.

Policie nemá žádné zákonné prostředky izolovat danou osobu za účelem, aby se osoba zbavila drogy v těle [10].

Je také otázkou, zda by to mělo nějaký význam, kdyby i policie tyto prostředky měla, protože po vyloučení drogy z těla u těchto osob většinou nastává těžký abstinenční stav. A navíc vše může trvat i několik dní. Také z těchto důvodů je na zvážení, zda by se měla osoba užívající OPL před každým výslechem podrobit orientačnímu testu, zda je pod vlivem drog nebo ne.

Neznamená to, že pokud osoba již není „pod vlivem“ (droga právě maximálně neúčinkuje), že tuto drogu nemá osoba v těle (v tělních tekutinách - krev, moč, sliny) [8].

Takto by byly některé osoby nevyslýchatelné. V praxi se musí bohužel přihlížet i k nemalé ceně jednotlivých orientačních testů, nastává zde tedy nereálnost testy provádět před každým výslechem.

Testy a př́ípadně i psychiatrické vyšetření se $\mathrm{v}$ praxi nutně provádí pouze u osob, které se jednorázově dopustí nějakého závažného trestného činu (loupež, těžké ublížení na zdraví, vražda) pro posouzení příčetnosti [14].

Samožrejmě u výslechu osob uživajících OPL záleží na daném policistovi, jak zhodnotí situaci a zda osobu vyslechne nebo ne.

Existují základní pravidla, která by měl znát každý, kdo jedná s osobou pod vlivem OPL [5]. Vyslýchající, tedy policista, by měl mít na mysli, že osoba intoxikovaná návykovou látkou může jednat nepřiměřeně, nepředvídatelně, zkratkovitě a neuváženě. To se týká zejména intoxikací alkoholem, pervitinem, kokainem a halucinogeny. Intoxikovaná osoba může mít sklon k vztahovačnosti a vykládat si i neutrální podněty ze svého okolí jako útok nebo své ohrožení. Takový člověk bývá také velmi citlivý na neverbální složky komunikace, jako je tón hlasu, gesta a vzdálenost [6].

Navrhuji zásady a doporučení směřující k efektivnějšímu provádění této kriminalisticko-taktické metody - výslechu se zaměřením na osoby pod vlivem návykových a psychotropních látek:

- Znalosti a vědomosti - znalost drogové problematiky, charakteristiku jednotlivých druhů drog a vliv těchto látek na lidský organismus.

- Reálnost provedení procesního úkonu - lékařské vyšetření ovlivněné osoby za účelem, zda bude dán souhlas lékaře k výslechu této osoby. Zjistit psychický a fyzický stav osoby.

- Účelnost - vyslechnout osobu s přihlédnutím k významu možnému výsledku ve srovnání s vynaloženým časem, technickými prostředky a lidským úsilím.

- Zákonnost - výslech musí být proveden v mezích zákona a každá vyslýchaní osoba musí být nejpozději na začátku výslechu poučena o svých právech.

- Obezřetnost - po celou dobu výslechu je třeba mít na paměti, že vyslýchaná osoba může být nebezpečná a pod vlivem drog může fyzicky ohrozit vyšetřovatele. Je vhodné před výslechem si zjistit, zda tato osoba již byla v kontaktu s policií, pokud ano, jak se přitom chovala a zda již byla souzena či odsouzena za jiný trestný čin či přestupky (vyhledat v informačních systémech trestní a přestupkovou minulost)

- Ostražitost - po celou dobu styku s vyslýchanou osobou zajistit vyšetřovateli minimálně další osobu ke střežení chování této osoby

- Operativnost a rychlost výslechu - je nutno brát v potaz, že osoba pod vlivem grog udrží pozornost jen po určitý čas a její zdravotní stav se může rychle změnit.

- Jednoduchost a srozumitelnost výslechu - otázky musí být jednoduché, jednoznačné a srozumitelné. Klást otevřené otázky. Vyvarovat se sugesci.

- Využití techniky - využití výpočetní a další techniky $\mathrm{k}$ protokolaci výslechu, $\mathrm{k}$ pořízení obrazového a zvukového 
záznamu průběhu výslechu, možnosti konferenčního sdílení větším množstvím zainteresovaných osob.

- Ochranná opatření (ochrana před nákazou) - mít připraveny a využít ochranné pomůcky a desinfekční prostředky při styku s osobou zneužívající drogy, která nedodržuje hygienu a může mít infekční choroby, o kterých ani nemusí vědět. Policista musí mít na paměti, že může dojít $\mathrm{k}$ přenosu nakažlivých chorob přímým kontaktem s infikovanou osobou. Po provedení výslechu je nutno vydesinfikovat místa, kde se osoba zdržovala a věci, kterých se dotýkala.

\section{ZÁVĚR}

Příspěvek poukazuje na nebezpečí současné doby, se kterým se policisté musí potýkat každý den ve své pracovní činnosti. Jsou to osoby pod vlivem omamných a psychotropních látek. Samozřejmě záleží na tom, zda jde o pachatele přestupků nebo trestného činu, svědka, či jde jen o osobu, která si aplikovala tuto látku a je třeba ji vykázat z určitého místa, popř́ípadě ji poskytnout první pomoc. Komunikace mezi policisty a ovlivněnou osobou závisí i na druhu omamné a psychotropní látky, kterou si ovlivněná osoba aplikovala a v jakém stavu se momentálně nachází.

Sepsala jsem zkušenosti policistů i své z jednání s narkomany a jak zjistit požadované informace, které policista potřebuje získat. Čerpala jsem z dlouholeté praxe své i mých kolegů policistů. Protože je občas důležité takovou osobu vyslechnout, v př́spěvku jsem navrhla zásady a doporučení, s nimiž je možné provádět tento procesní úkon efektivně a pokud možno bezpečně.

\section{LITERATURA}

[1] ČÍRTKOVÁ, L. Forenzni psychologie. Aleš Čeněk, Plzeň, 2013, 446 s. ISBN 978-80-7380-461-9.

[2] CHMELÍK, J. a kol. Drogová kriminalita. Úřad vyšetřování pro ČR, MVČR, Praha, 1999, 96 s.

[3] KONRÁD, Z., MUSIL, J. a kol. Metodika vyšetřováni jednotlivých druhů trestných činů. Policejní akademie ČR, Praha, 1996, 219 s. ISBN 80-85981-39-8.

[4] MATIÁŠEK, J., SOUKUP, J., BÁRTA, B. Psychologie a výslechová praxe. Orbis, Praha, 1968, $250 \mathrm{~s}$.

[5] NĚMEC, M. Vybrané problémy kriminalistické taktiky. Armex, Praha, 1999, 103 s. ISBN, 80-86244-05-9.

[6] NEŠPOR, K., DVOŘÁK, V. Prevence trestné činnosti souvisejicí s návykovými látkami. Armex, Praha, 1998, $98 \mathrm{~s}$.

ISBN 80-902283-9-9.

[7] NOŽINA, M. Svět drog v Čechách. KLP - Koniasch Latin Press, Praha, 1997, 347 s. ISBN 8085917-36-X.

[8] RABOCH, J., JIRÁK, R., PACLT, I. Psychofarmakologie pro praxi. Triton, Praha, 2007, 167 s. ISBN 978-80-7387-041-6.

[9] STRAUS, J., VIKTORYOVÁ, J. a kol. Metodika vyšetřování drogové kriminality. Policejní akademie ČR, Praha, 2006, 47 s. ISBN 80-7251-219-6.

[10] SVOBODA, M. Psychologická diagnostika dospělých. Portál, Praha, 2005, 320 s. ISBN: 80-7367-050-X.

[11] VOKUŠ, J. Policie České republiky: Police of the Czech Republic: pomáhat a chránit. Policejní prezidium České republiky, Praha, 2010, 85 s. ISBN 978-80-254-7701-4.

[12] VYKOPALOVÁ, H. Vybrané kapitoly ze sociální psychologie $v$ kontextu komunikace. Univerzita Palackého v Olomouci, Olomouc, 2000, 198 s. ISBN 80-244-0084-7.

[13] VIKTORYOVÁ, J. PALAREC, J., BLATNICKÝ, J. Vyšetrovanie farmaceutickej trestnej činnosti. Akadémia Policajného zboru v Bratislave, Bratislava, 2017, 74 s. ISBN 978-80-8054-748-6.

[14] Ottưv slovník naučný: Příčetnost. [online]. [cit. 7.7. 2018]. Dostupné z: https://cs.wikisource.org/wiki/ Ott $\%$ C5\%AFv_slovn $\%$ C $3 \% A D k \_n a u \% C 4 \% 8 D n \% C 3 \% B D /$ P\%C5\%99\%C3\%AD\%C4\%8Detnost

\section{Správná citace:}

KOPENCOVÁ, D. Specifičnost komunikace policistů s osobami pod vlivem omamných a psychotropních látek. Soudní inženýrství, 2019, 30(2), 49-55. DOI: http://dx.doi.org./10.13164/SI.2019.2.49. ISSN 1211-443X. 